Document downloaded from:

http://hdl.handle.net/10251/74109

This paper must be cited as:

Molines, J.; Medina Folgado, JR. (2015). Calibration of overtopping roughness factors for concrete armor units in non-breaking conditions using the CLASH database. Coastal Engineering. 96:62-70. doi:10.1016/j.coastaleng.2014.11.008.

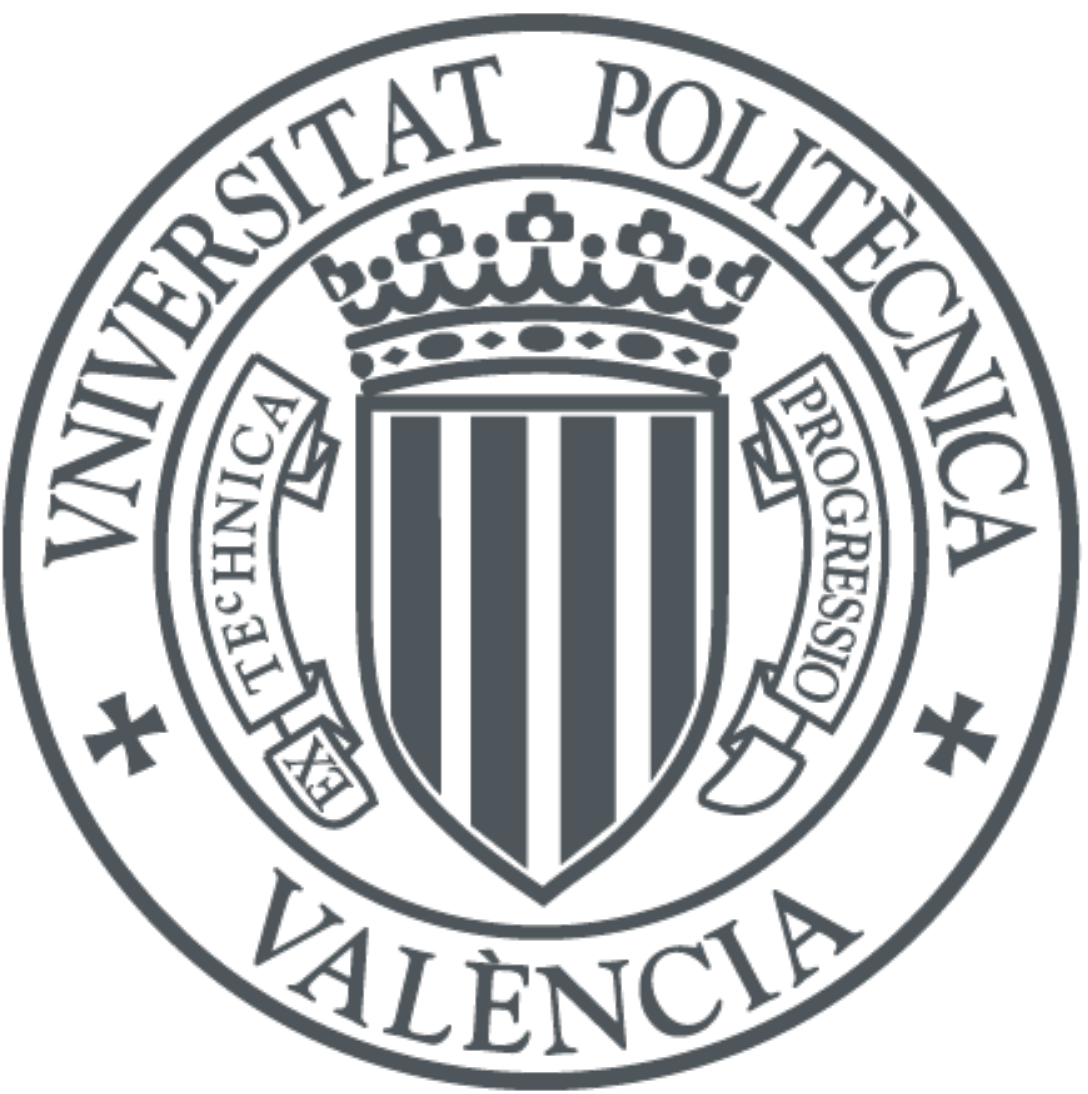

The final publication is available at

http://dx.doi.org/10.1016/j.coastaleng.2014.11.008

Copyright Elsevier

Additional Information 


\title{
Calibration of overtopping roughness factors for concrete armor units in non-breaking conditions using the CLASH database
}

\author{
Jorge Molines $^{\mathrm{a}, *}$ and Josep R. Medina ${ }^{\mathrm{b}}$ \\ ${ }^{a}$ Research Assistant, Dept. of Transportation, Universitat Politècnica de València, Camino de Vera s/n, 46022 \\ Valencia, Spain. E-mail: jormollo@upvnet.upv.es (*corresponding author) \\ ${ }^{b}$ Professor, Dept. of Transportation, Universitat Politècnica de València, Camino de Vera s/n, 46022 Valencia, Spain. \\ E-mail: jrmedina@upv.es
}

\section{Introduction}

The estimation of wave overtopping on breakwaters is a major design issue because it affects crest elevation and operational conditions. The overtopping rates on a mound breakwater depend on structural and environmental conditions. One of the structural characteristics is the roughness factor, $\gamma_{f}$; the higher the roughness factor, the higher the overtopping rates. The roughness factor, $\gamma_{f}$, takes into account how overtopping is influenced by the armor unit geometry, the number of layers, the packing density, the permeability of the filter and core as well as other structural characteristics. Fig. 1 illustrates the armor roughness of a smooth slope, $\gamma_{\mathrm{f}}=1.00$, and a cube-armored slope, $\gamma_{\mathrm{f}}=0.50$.

a)

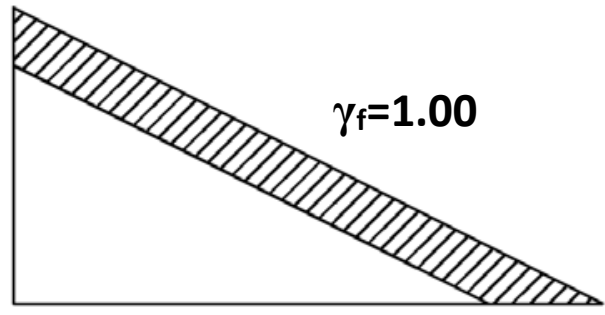

b)

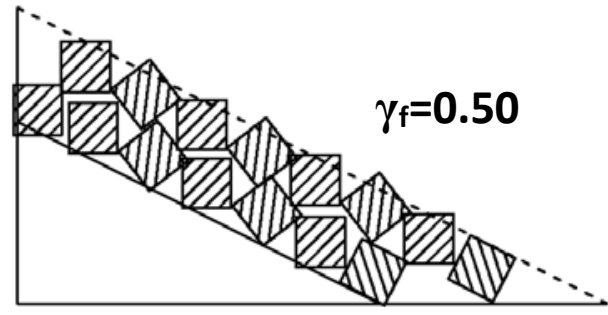

Figure 1. (a) Smooth slope and (b) double-layer randomly-placed cube armored slope. 
Table 1 summarizes the roughness factors given by different authors and for different armor units. According to TAW (1974), the first roughness factors based on regular waves and run-up observations were published in Russian manuals. Owen (1980) used the roughness factors $\left(\gamma_{f}\right)$ to estimate wave overtopping as the ratio between the runup of a given wave on a rough slope and the run-up of the same wave on a smooth slope. Van der Meer and Janssen (1994) proposed calculating the $\gamma_{f}$ for dikes and rock slopes by comparing the run-up of a rough slope with that of a smooth one. Lykke and Burchart (2004) pointed out that $\gamma_{f}$ based on run-up measurements may not be adequate to estimate overtopping rates. For rock and cube armor units, Lykke and Burchart (2004) analyzed the correction factor given by Besley (1999) to take into account a permeable crest berm in both Owen's (1980) and Van der Meer and Janssen's (1994) formulas. The correction factor decreased the scatter on the data in both formulas; however, the best corrected formulas required different $\gamma_{f}$ for the same armor unit, and in both cases these were different from the roughness factors originally proposed by Owen (1980) and Van der Meer and Janssen (1994).

Hebsgaard et al. (1998) developed an overtopping formula adjusting the coefficients of the formula to obtain the best fit when using a fixed $\gamma_{f}=0.55$ for double-layer rock armors, following the $\gamma_{f}$ recommended by other researchers.

As part of the European CLASH Project (2001-2003), a set of $\gamma_{f}$ based on overtopping measurements for different armor units was provided by Pearson et al. (2004). Those roughness factors were calibrated considering results from a specific cross-section and using the formula given by Van der Meer and Janssen (1994). Pearson et al. (2004) 
factored all the initial $\gamma_{f}$ values, the $\gamma_{f}$ for the smooth slope being $\gamma_{f}=1.00$; as $\gamma_{f}$ obtained from smooth slope data was $\gamma_{f}=1.05$, a $5 \%$ reduction was imposed on all values.

The European CLASH Project collected results from 10,532 overtopping tests corresponding to a variety of coastal structures (see Verhaeghe et al., 2003 and Van der Meer et al., 2009). The CLASH database was created as the foundation for a generic overtopping prediction method based on artificial neural networks (see Van Gent et al., 2007). The CLASH neural network (CLNN) uses the $\gamma_{f}$ given by Coeveld et al. (2005), which are slightly different from those derived by Pearson et al. (2004) which were also obtained within the CLASH Project.

The CLNN uses 3 input variables to describe the characteristics of the incident waves and 12 input variables to describe the characteristics of the structure (see Fig. 2).

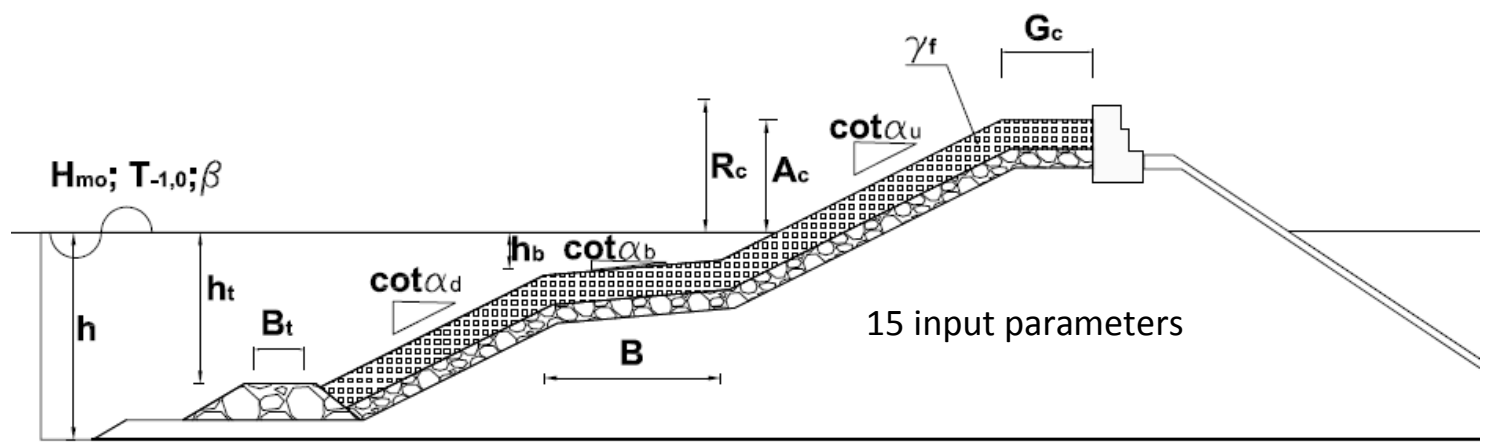

Figure 2. CLASH breakwater cross-section considered for the CLNN.

$R_{c}$ is the breakwater crest freeboard; $A_{c}$ is the armor crest freeboard; $G_{c}$ is the breakwater crest width; $\cot \alpha_{d}$ is the slope of the structure downward from the berm; $\cot \alpha_{u}$ is the slope of the structure upward from the berm; $B$ is the width of the berm; $\cot \alpha_{b}$ is the slope of the berm; $h_{b}$ is the water depth on the berm; $h$ is the water depth in front of the structure; $h_{t}$ is the water depth at the toe of the structure; $B_{t}$ is the width 
of the toe berm; $\beta$ is the angle of wave attack; $H_{m 0}=4\left(m_{0}\right)^{0.5}$ is the significant wave height at the toe of the structure; $T_{-1,0}=m_{-1} / m_{0}$ is the mean spectral wave period at the toe of the structure, being $m_{n}$ the $n^{\text {th }}$ spectral moment, and $\gamma_{f}$ is the roughness factor given by Coeveld et al. (2005).

Bruce et al. (2006) reported specific tests and results from Pearson et al. (2004) and listed $\gamma_{f}$ for different armor units which were used in the formulas given by EurOtop (2007). Bruce et al. (2009) re-examined the tests reported by Bruce et al. (2006), proposing certain changes in the $\gamma_{f}$ and calculating the confidence intervals for each $\gamma_{f}$ by analyzing variance. Overtopping rates were measured in specific small-scale tests for mound breakwaters without toe berm $\left(B_{t}=0\right) ; \cot \alpha=1: 1.5 ; R_{c}=A_{c}$ and $G_{c}=3 D_{n}$ (where $D_{n}$ is the nominal diameter).

Smolka et al. (2009) carried out overtopping tests using cube and Cubipod-armored breakwaters, proposing a new 4-parameter formula (described in section 2). The proposed roughness factors were those which best fitted the results for double-layer cube and single- and double-layer Cubipod armors.

Van der Meer and Bruce (2014) proposed revising EurOtop (2007) formulas in order to account for low and zero crest freeboard $\left(R_{c} / H_{m 0}<0.5-1.00\right)$. In this revision, the roughness factors to be used in the new overtopping formula were not specified.

Kortenhaus et al. (2014) obtained the roughness factors for single- and double-layer Haro armors which best fitted their tests using formulas given by Van der Meer and Janssen (1994) and Van der Meer and Bruce (2014). The former resulted in $\gamma_{\mathrm{f}}=0.57$ and the latter in $\gamma_{\mathrm{f}}=0.63$. Their tested model was similar to that analyzed by Pearson et al. (2004) who proposed $\gamma_{\mathrm{f}}=0.47$; Kortenhaus et al. (2014) suggested that the differences in 
$\gamma_{f}$ values were due to either model or scale effects, and thus the need for a more detailed analysis.

Table 1 shows different sets of roughness factors for mound breakwaters with permeable cores as proposed in the literature for a variety of overtopping prediction formulas. It must be stated that each set of $\gamma_{f}$ is reliable only for the overtopping formula given by the corresponding author. The values underlined are estimated by Pearson et al. (2004), Bruce et al. (2006) and Bruce et al. (2009). Pearson et al. (2004), Bruce et al. (2006) and Bruce et al. (2009) gave values of the tested packing densities (all the papers were based on the same tests) in which Dolos armor units were not tested. For Cubipods, packing densities were taken from Smolka et al. (2009).

\begin{tabular}{|c|c|c|c|c|c|c|c|c|}
\hline $\begin{array}{l}\text { Type of armor } \\
2 \mathrm{~L}=\text { double-layer } \\
1 \mathrm{~L}=\text { single-layer }\end{array}$ & 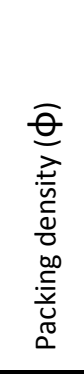 & 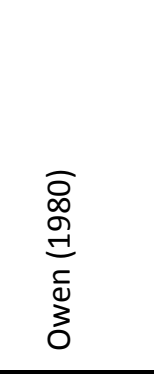 & 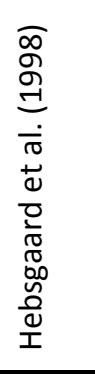 & 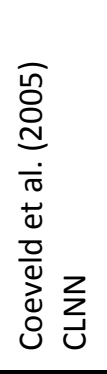 & 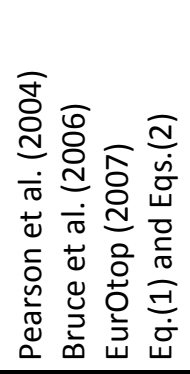 & 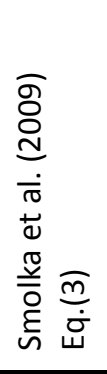 & 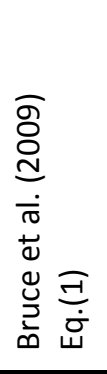 & 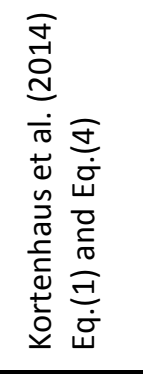 \\
\hline Smooth & - & 1.00 & - & 1.00 & 1.00 & - & 1.00 & - \\
\hline Rock (2L) & 1.38 & $0.50-0.60$ & 0.55 & 0.50 & 0.40 & - & 0.40 & - \\
\hline Cube (2L, random) & 1.17 & - & - & 0.50 & 0.47 & 0.50 & 0.47 & - \\
\hline Cube (2L, flat) & 1.17 & - & - & - & 0.47 & - & 0.47 & - \\
\hline Cube (1L, flat) & 0.70 & - & - & - & 0.50 & - & 0.49 & - \\
\hline Antifer (2L) & 1.17 & - & 0.65 & 0.50 & 0.47 & - & 0.50 & - \\
\hline $\operatorname{Haro}^{R}(2 \mathrm{~L})$ & - & - & - & 0.47 & 0.47 & - & 0.47 & $0.57 / 0.63$ \\
\hline $\operatorname{Haro}^{R}(1 \mathrm{~L})$ & - & - & - & - & - & - & - & $0.57 / 0.63$ \\
\hline Tetrapod (2L) & 1.04 & - & - & 0.40 & 0.38 & - & 0.38 & - \\
\hline Accropode $^{\mathrm{TM}}(1 \mathrm{~L})$ & 0.62 & - & 0.55 & 0.49 & 0.46 & - & 0.46 & - \\
\hline Core-Loc ${ }^{\mathrm{TM}}(1 \mathrm{~L})$ & 0.56 & - & - & 0.47 & 0.44 & - & 0.44 & - \\
\hline
\end{tabular}




\begin{tabular}{lcccccccc}
\hline $\operatorname{Xbloc}^{R}(\mathrm{~L})$ & 0.58 & - & - & 0.49 & 0.45 & - & 0.44 & - \\
\hline Dolos $(2 \mathrm{~L})$ & - & - & 0.45 & 0.43 & $\underline{0.43}$ & - & $\underline{0.43}$ & - \\
\hline Cubipod $^{R}(2 \mathrm{~L})$ & 1.18 & - & - & - & - & 0.44 & - & - \\
Cubipod $^{R}(1 \mathrm{~L})$ & 0.61 & - & - & - & - & 0.46 & - & - \\
\hline
\end{tabular}

Table 1. Roughness factors $\left(\gamma_{f}\right)$ given in the literature.

a)

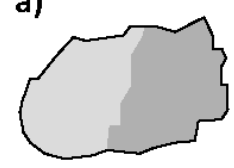

f)

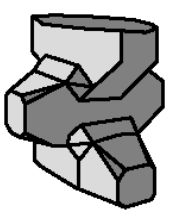

b)

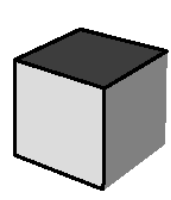

g)

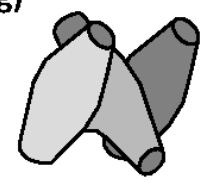

c)

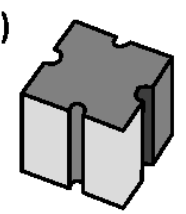

h)

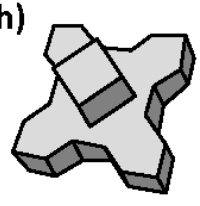

d)

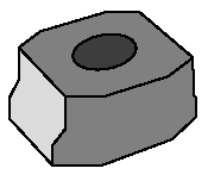

i)

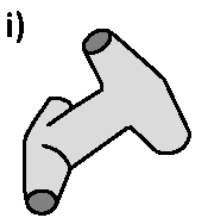

e)

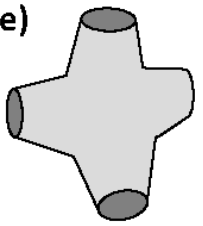

j)

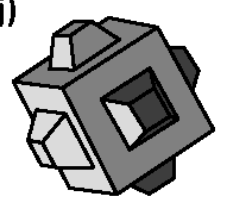

Figure 3. Concrete armor units: (a) rock; (b) cube; (c) Antifer; (d) Haro ${ }^{\mathrm{R}}$; (e) Tetrapod; (f) Accropode $^{\mathrm{TM}}$; (g) Core-loc ${ }^{\mathrm{TM}}$; (h) Xbloc ${ }^{\mathrm{R}}$; (i) Dolos and (j) Cubpod ${ }^{\mathrm{R}}$.

The roughness factor is usually considered a parameter associated with the armor unit geometrical shape; however, $\gamma_{\mathrm{f}}$ is dependent not only on the armor unit geometry, but also on the packing density, number of layers and other structural characteristics. Furthermore, in this study, $\gamma_{f}$ is also considered dependent on the specific empirical formulas in which $\gamma_{f}$ is included.

In this paper, an overtopping background is given first. Secondly, the datasets extracted from the CLASH database are described in detail. Thirdly, a methodology to calibrate the armor roughness factors is described. Fourthly, the roughness factors and confidence intervals to be used along with different overtopping formulas are given. Fifthly, the influence of packing density and armor roughness is analyzed. Finally, a sensitivity analysis is provided and conclusions are drawn. 


\section{Selected overtopping formulas}

This study considers some of the most popular overtopping formulas which include the roughness factor as an explicative variable. Nevertheless, the methodology used in this study is applicable to any empirical formula or overtopping prediction tool which includes the roughness factor as an explicative variable.

Eq. (1) is a well-known formula initially proposed by Van der Meer and Janssen (1994) to estimate wave overtopping on dikes in non-breaking conditions.

$Q_{V M J}=\frac{q}{\sqrt{g \cdot H_{m 0}^{3}}}=A_{1} \cdot \exp \left(-A_{2} \cdot \frac{R_{c}}{H_{m 0}} \cdot \frac{1}{\gamma_{f}}\right)$

where $A_{1}=0.2, A_{2}=2.6$, and $\gamma_{f}$ is used to consider the effect of the slope roughness. EurOtop (2007) suggested using Eq. (1) with the $\gamma_{f}$ given by Bruce et al. (2006) and corrected the first estimation with Eqs. (2) proposed by Besley (1999) if $G_{c}>3 D_{n}$.

$$
\begin{aligned}
& C r=\min \left[1.0 ; B_{1} \cdot \exp \left(-B_{2} \cdot \frac{G_{c}}{H_{m 0}}\right)\right] \\
& Q_{\text {EurOtop }}=\frac{q}{\sqrt{g \cdot H_{m 0}^{3}}}=C r \cdot Q_{V M J}
\end{aligned}
$$

where $\mathrm{Cr}$ is the reduction factor, $B_{1}=3.06$, and $B_{2}=1.5$. If $G_{c} / H_{m 0}<0.75$, there is no reduction in wave overtopping $(\mathrm{Cr}=1)$. Initially, Eqs. (2) were derived by Besley (1999) to correct the formula given by Owen (1980), valid for rock slopes and $R_{c}=A_{c}$. Besley (1999) reported that Eqs. (2) can conservatively be applied to other permeable structures.

Eq. (1) is a simple and robust formula with only two parameters $\left(A_{1}=0.2\right.$ and $\left.A_{2}=-2.6\right)$. The corresponding ranges of application for the slope angle, relative crest freeboard and 
Iribarren's number in Eq. (1) are $1.0<\cot \alpha<4.0,0.5<R_{c} / H_{m 0}<3.5$, and $I r_{p}=$ $T_{p} / \cot \alpha\left[2 \pi H_{m o} / g\right]^{0.5}>2$. The reliability of Eq. (1) is expressed by considering $B_{2}=-2.6$, as a normally distributed random variable $\mathrm{N}\left(-2.6,0.35^{2}\right)$.

Van Gent et al. (2007) described the CLASH neural network (CLNN) based on the CLASH database. The CLNN was created using a bootstrapping technique to train 500 artificial neural networks to estimate overtopping rates and confidence intervals. The CLNN gives no prediction when an input variable is out of its application range or when dimensionless overtopping rates are very low, $q / \sqrt{g \cdot H_{m 0}^{3}}=Q<10^{-6}$. One of the input variables of the CLNN is the $\gamma_{f}$ given by Coeveld et al. (2005). In this study, $Q_{C L N N}$ refers to the overtopping discharge estimated using the CLNN.

For cube- and Cubipod-armored breakwaters, Smolka et al. (2009) proposed the following overtopping formula:

$Q_{S Z M}=\frac{q}{\sqrt{g \cdot H_{m 0}^{3}}}=C_{1} \cdot \exp \left(C_{2} \cdot \operatorname{Irp}-C_{3} \cdot \frac{A_{c}}{R_{c}}-C_{4} \frac{R_{c}}{H_{m 0}} \cdot \frac{1}{\gamma_{f}}\right)$

where $C_{1}=0.2, C_{2}=0.53, C_{3}=3.27, C_{4}=2.16, I r_{p}=T_{p} / \cot \alpha\left[2 \pi H_{m 0} / g\right]^{0.5}, \gamma_{f}$ [cube $2 \mathrm{~L}$ random] $=0.50, \gamma_{f}\left[\right.$ Cubipod 1L] $=0.46$, and $\gamma_{f}[$ Cubipod 2L] $=0.44$. Tests by Smolka et al. (2009) were conducted in the ranges of $2.7<I r_{p}<7.0, \cot \alpha=1.5,0.70<A_{c} / R_{c}$ [cube $2 \mathrm{~L}$ random] $<1.00,0.40<A_{d} / R_{c}$ [Cubipod $1 \mathrm{~L}$ ] $<0.65,0.58<A_{d} / R_{c}$ [Cubipod $2 \mathrm{~L}$ ] $<0.80$, and $1.30<R_{c} / H_{m o}<2.80$. This overtopping formula was selected as an example of a formula which was obtained and calibrated from specific laboratory tests.

Recently, Van der Meer and Bruce (2014) proposed revising the $Q_{V M J}$ formula to describe overtopping on sloping structures with zero and positive freeboard in non-breaking conditions: 
$Q_{V M B}=\frac{q}{\sqrt{g \cdot H_{m 0}^{3}}}=D_{1} \cdot \exp \left(-\left(D_{2} \cdot \frac{R_{c}}{H_{m 0}} \cdot \frac{1}{\gamma_{f}}\right)^{D 3}\right)$

where $D_{1}=0.09, D_{2}=1.5$, and $D_{3}=1.3$. Van der Meer and Bruce (2014) pointed out that Eq. (4) gives almost the same overtopping discharge estimations as Eq. (1), but better estimations for low and zero crest freeboards $\left(R_{c} / H_{m 0}<0.5-1.0\right)$. The reliability of Eq. (4) is expressed by considering $D_{1}=0.09$, as a normally distributed random variable $\mathrm{N}(0.09$, $\left.0.013^{2}\right)$ and $D_{2}=1.5$ as $\mathrm{N}\left(1.5,0.15^{2}\right)$.

\section{Datasets from CLASH database}

This paper focuses on mound breakwaters with crown wall, corresponding to the crosssection depicted in Fig. 4, and referred to as conventional mound breakwaters. This is the most common typology for mound breakwaters, especially when concrete armor units are used.

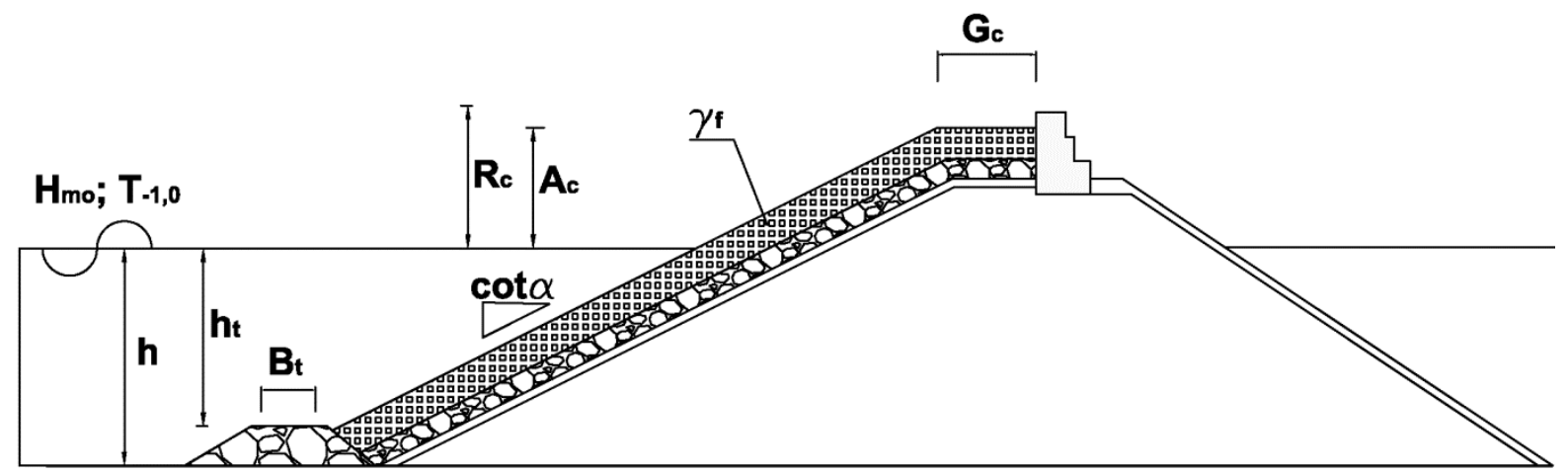

Figure 4. Conventional mound breakwater cross-section.

This study used the overtopping measurements for conventional mound breakwaters included in the CLASH database. For Cubipod-armored breakwaters, the tests conducted by Smolka et al. (2009) were used. The structural characteristics of the tests by Smolka 
et al. (2009) were $\cot \alpha=1.5, G_{c}[\mathrm{~m}]=0.12$, and $B_{t}[\mathrm{~m}]=0$. Appendix A provides the overtopping results from the small-scale tests reported by Smolka et al. (2009).

To select the data corresponding to conventional mound breakwaters, the following data filters were applied to the CLASH database: $\beta=0, \cot \alpha_{d}=\cot \alpha_{u}=\cot \alpha, 1.19 \leq \cot \alpha \leq 4$, $B=0, \tan \alpha_{b}=0, h_{b}=0, R F \leq 2, C F=1$, non-breaking conditions $\left(1.8 H_{\text {motoe }}<0.8 h\right.$ and/or $/ r_{p}=$ $T_{\text {ptoe }} / \cot \alpha\left[2 \pi H_{\text {motoe }} / \mathrm{g}\right]^{0.5}>2$ to ensure no wave breaking) and $Q \geq 10^{-6} . R F$ is the Reliability Factor $(1 \leq R F \leq 4)$ to account for the quality of the test, and $C F$ is the Complexity Factor $(1 \leq C F \leq 4)$ to account for the complexity of the cross section, both defined in Van Gent et al. (2007). Furthermore, tests with remarks and/or without references were removed. The CLASH database (http://www.clash.ugent.be/) identified the armor type using the values of $\gamma_{f}$ listed by Bruce et al. (2006). For cases in which one value of $\gamma_{f}$ identified two or more armor units, it was necessary to check the reference to correctly identify the tests corresponding to each armor unit. Test data provided by Stewart et al. (2002), corresponding to tightly-packed rock armor, were removed given the divergence between the roughness factor found in the CLASH database, $\gamma_{f}=0.40$, and $\gamma_{f}=0.75$ proposed by Stewart et al. (2002). For smooth slopes, tests with $R_{c}[\mathrm{~m}]=0$ were removed since they are not within the common range of conventional mound breakwaters. For Dolos, only 8 tests with references are available in the database, so all were used. After applying the filter described above, a total of 1,183 of 10,532 tests were selected. Table 3 specifies the characteristics of the overtopping tests extracted from the CLASH database and Smolka et al. (2009). Table 3 also specifies the applicability range of the roughness factors derived in this study. Given a specific armor unit, selecting the same dataset for all the overtopping formulas allows for the direct comparison of the results. 
The relative Mean Squared Error ( $r M S E)$ of $\log Q$, similar to that used in Van Gent et al. (2007), is used here to measure the quality of the overtopping estimator " $\mathrm{e}$ " when applied to a group of target or observed data "o" $(\mathrm{i}=1,2, \ldots, \mathrm{N})$. The $r M S E$ corresponding to overtopping estimator " $\mathrm{e}$ " and observations " $\mathrm{o}$ " is given by:

$$
r \operatorname{MSE}_{e}(o)=\frac{\operatorname{MSE}_{e}(o)}{\operatorname{Var}(o)}=\frac{\sum_{i=1}^{N} W F_{i}\left(\log Q e_{i}-\log Q o_{i}\right)^{2}}{\left(\sum_{i=1}^{N} W F_{i}\right) \cdot \operatorname{Var}(\log Q o)}
$$

where $N$ is the total number of data; $i$ is the data index; $W F$ is the weight factor given in Table 2 from CLASH (see Van Gent et al., 2007); Qe and Qo are the estimated and target dimensionless mean overtopping discharges using estimator " $\mathrm{e}$ " and target data "o". $0 \%<r M S E_{e}(0)<100 \%$ indicates the proportion of variance of the data not explained by the estimator " $\mathrm{e}$ ".

\begin{tabular}{ll}
\hline $\boldsymbol{R} \boldsymbol{F}$ & $\boldsymbol{W F}$ \\
\hline 1 & 9 \\
\hline 2 & 6 \\
\hline
\end{tabular}

Table 2. Weight Factor dependent on the Reliability Factor. 


\begin{tabular}{|c|c|c|c|c|c|c|c|c|c|c|c|}
\hline Armor type & Datasets & $\begin{array}{l}\text { No. } \\
\text { data }\end{array}$ & $\begin{array}{l}H_{m 0} \\
{[\mathrm{~m}]}\end{array}$ & $\begin{array}{l}T_{-1,0} \\
{[\mathrm{~s}]}\end{array}$ & $\begin{array}{l}R_{c} \\
{[\mathrm{~m}]}\end{array}$ & $\begin{array}{l}A_{c} \\
{[\mathrm{~m}]}\end{array}$ & $\begin{array}{l}G_{c} \\
{[\mathrm{~m}]}\end{array}$ & $\cot \alpha$ & $\begin{array}{l}h_{t} \\
{[\mathrm{~m}]}\end{array}$ & $\begin{array}{l}h \\
{[\mathrm{~m}]}\end{array}$ & $\begin{array}{l}B_{t} \\
{[\mathrm{~m}]}\end{array}$ \\
\hline Smooth & $\begin{array}{l}30,35,42, \\
102,103, \\
218,220, \\
221,222, \\
226,227, \\
703\end{array}$ & 226 & $\begin{array}{l}0.027- \\
0.203\end{array}$ & $\begin{array}{l}0.679- \\
3.647\end{array}$ & $\begin{array}{l}0.040- \\
0.55\end{array}$ & $\begin{array}{l}0.040- \\
0.55\end{array}$ & 0.000 & $\begin{array}{l}1.19- \\
4.00\end{array}$ & $\begin{array}{l}0.080- \\
0.720\end{array}$ & $\begin{array}{l}0.160- \\
0.720\end{array}$ & $\begin{array}{l}0.000- \\
0.800\end{array}$ \\
\hline $\begin{array}{l}\text { Rock } \\
(2 \mathrm{~L})\end{array}$ & $\begin{array}{l}32,35, \\
331,510, \\
701,702, \\
705,954, \\
958\end{array}$ & 555 & $\begin{array}{l}0.051- \\
0.203\end{array}$ & $\begin{array}{l}0.800- \\
2.560\end{array}$ & $\begin{array}{l}0.062- \\
0.370\end{array}$ & $\begin{array}{l}0.010- \\
0.300\end{array}$ & $\begin{array}{l}0.000- \\
0.360\end{array}$ & $\begin{array}{l}1.33- \\
4.00\end{array}$ & $\begin{array}{l}0.087- \\
0.730\end{array}$ & $\begin{array}{l}0.138- \\
0.730\end{array}$ & $\begin{array}{l}0.000- \\
0.140\end{array}$ \\
\hline $\begin{array}{l}\text { Cubes } \\
(2 \mathrm{~L}, \text { random) }\end{array}$ & $\begin{array}{l}331,510 \\
702,705\end{array}$ & 171 & $\begin{array}{l}0.041- \\
0.177\end{array}$ & $\begin{array}{l}0.747- \\
2.854\end{array}$ & $\begin{array}{l}0.070- \\
0.263\end{array}$ & $\begin{array}{l}0.070- \\
0.240\end{array}$ & $\begin{array}{l}0.089- \\
0.351\end{array}$ & $\begin{array}{l}1.33- \\
2.50\end{array}$ & $\begin{array}{l}0.405- \\
0.722\end{array}$ & $\begin{array}{l}0.405- \\
0.722\end{array}$ & $\begin{array}{l}0.000- \\
0.130\end{array}$ \\
\hline $\begin{array}{l}\text { Cubes } \\
\text { (2L, flat) }\end{array}$ & 510 & 28 & $\begin{array}{l}0.044- \\
0.102\end{array}$ & $\begin{array}{l}0.751- \\
1.542\end{array}$ & $\begin{array}{l}0.071- \\
0.118\end{array}$ & $\begin{array}{l}0.071- \\
0.116\end{array}$ & 0.089 & $\begin{array}{l}1.50- \\
2.00\end{array}$ & $\begin{array}{l}0.677- \\
0.724\end{array}$ & $\begin{array}{l}0.677- \\
0.724\end{array}$ & 0.000 \\
\hline $\begin{array}{l}\text { Cubes } \\
\text { (1L, flat) }\end{array}$ & 510 & 16 & $\begin{array}{l}0.045- \\
0.097\end{array}$ & $\begin{array}{l}0.795- \\
1.540\end{array}$ & $\begin{array}{l}0.071- \\
0.116\end{array}$ & $\begin{array}{l}0.071- \\
0.116\end{array}$ & 0.089 & 1.50 & $\begin{array}{l}0.678- \\
0.721\end{array}$ & $\begin{array}{l}0.678- \\
0.721\end{array}$ & 0.000 \\
\hline $\begin{array}{l}\text { Antifer } \\
(2 L)\end{array}$ & 379,510 & 25 & $\begin{array}{l}0.048- \\
0.136\end{array}$ & $\begin{array}{l}0.791- \\
2.191\end{array}$ & $\begin{array}{l}0.079- \\
0.180\end{array}$ & $\begin{array}{l}0.079- \\
0.180\end{array}$ & $\begin{array}{l}0.099- \\
0.150\end{array}$ & 1.50 & $\begin{array}{l}0.400- \\
0.725\end{array}$ & $\begin{array}{l}0.400- \\
0.725\end{array}$ & 0.000 \\
\hline $\begin{array}{l}\text { Haro }^{R} \\
(2 \mathrm{~L})\end{array}$ & 510 & 15 & $\begin{array}{l}0.044- \\
0.101\end{array}$ & $\begin{array}{l}0.751- \\
1.540\end{array}$ & $\begin{array}{l}0.071- \\
0.118\end{array}$ & $\begin{array}{l}0.071- \\
0.118\end{array}$ & $\begin{array}{l}0.078- \\
0.089\end{array}$ & 1.50 & $\begin{array}{l}0.678- \\
0.724\end{array}$ & $\begin{array}{l}0.678- \\
0.724\end{array}$ & 0.000 \\
\hline $\begin{array}{l}\text { Tetrapod } \\
(2 \mathrm{~L})\end{array}$ & $\begin{array}{l}331,379, \\
510\end{array}$ & 86 & $\begin{array}{l}0.079- \\
0.136\end{array}$ & $\begin{array}{l}0.952- \\
2.191\end{array}$ & $\begin{array}{l}0.081- \\
0.024\end{array}$ & $\begin{array}{l}0.081- \\
0.180\end{array}$ & $\begin{array}{l}0.105- \\
0.351\end{array}$ & $\begin{array}{l}1.33- \\
2.00\end{array}$ & $\begin{array}{l}0.400- \\
0.731\end{array}$ & $\begin{array}{l}0.400- \\
0.731\end{array}$ & 0.000 \\
\hline $\begin{array}{l}\text { Accropode }^{T M} \\
(1 L)\end{array}$ & 510 & 14 & $\begin{array}{l}0.069- \\
0.118\end{array}$ & $\begin{array}{l}0.948- \\
1.640\end{array}$ & $\begin{array}{l}0.086- \\
0.139\end{array}$ & $\begin{array}{l}0.086- \\
0.139\end{array}$ & 0.095 & 1.50 & $\begin{array}{l}0.674- \\
0.727\end{array}$ & $\begin{array}{l}0.674- \\
0.727\end{array}$ & 0.000 \\
\hline $\begin{array}{l}\text { Core-Loc } \\
\text { (1L) }\end{array}$ & 379,510 & 27 & $\begin{array}{l}0.060- \\
0.136\end{array}$ & $\begin{array}{l}0.951- \\
2.191\end{array}$ & $\begin{array}{l}0.086- \\
0.181\end{array}$ & $\begin{array}{l}0.086- \\
0.181\end{array}$ & $\begin{array}{l}0.089- \\
0.150\end{array}$ & 1.50 & $\begin{array}{l}0.400- \\
0.727\end{array}$ & $\begin{array}{l}0.400- \\
0.727\end{array}$ & 0.000 \\
\hline $\begin{array}{l}\text { Xbloc }{ }^{R} \\
(1 \mathrm{~L})\end{array}$ & 510 & 12 & $\begin{array}{l}0.075- \\
0.115\end{array}$ & $\begin{array}{l}0.952- \\
1.642\end{array}$ & $\begin{array}{l}0.090- \\
0.142\end{array}$ & $\begin{array}{l}0.090- \\
0.142\end{array}$ & 0.090 & 1.50 & $\begin{array}{l}0.673- \\
0.728\end{array}$ & $\begin{array}{l}0.673- \\
0.728\end{array}$ & 0.000 \\
\hline $\begin{array}{l}\text { Dolos } \\
(2 \mathrm{~L})\end{array}$ & 702 & 8 & $\begin{array}{l}0.122- \\
0.177\end{array}$ & $\begin{array}{l}1.091- \\
2.000\end{array}$ & $\begin{array}{l}0.200- \\
0.240\end{array}$ & $\begin{array}{l}0.110- \\
0.150\end{array}$ & 0.180 & 2.50 & $\begin{array}{l}0.550- \\
0.590\end{array}$ & $\begin{array}{l}0.550- \\
0.590\end{array}$ & 0.000 \\
\hline $\begin{array}{l}\text { CubipodR } \\
(2 L)\end{array}$ & Table 6 & 65 & $\begin{array}{l}0.089- \\
0.157\end{array}$ & $\begin{array}{l}1.045- \\
2.780\end{array}$ & $\begin{array}{l}0.203- \\
0.263\end{array}$ & $\begin{array}{l}0.150- \\
0.200\end{array}$ & 0.120 & 1.50 & $\begin{array}{l}0.500- \\
0.550\end{array}$ & $\begin{array}{l}0.500- \\
0.550\end{array}$ & 0.000 \\
\hline $\begin{array}{l}\text { Cubipod }{ }^{R} \\
\text { (1L) }\end{array}$ & Table 7 & 59 & $\begin{array}{l}0.075- \\
0.158\end{array}$ & $\begin{array}{l}0.978- \\
2.683\end{array}$ & $\begin{array}{l}0.203- \\
0.263\end{array}$ & $\begin{array}{l}0.110- \\
0.160\end{array}$ & 0.120 & 1.50 & $\begin{array}{l}0.500- \\
0.550\end{array}$ & $\begin{array}{l}0.500- \\
0.550\end{array}$ & 0.000 \\
\hline
\end{tabular}

Table 3. Test data extracted from the CLASH database and Smolka et al. (2009).

\section{Methodology to estimate the roughness factors $\left(\gamma_{f}\right)$}

Considering a specific overtopping predictor and a given dataset, rMSE (Eq. 5) can be used to estimate the optimum $\gamma_{f}$ which minimizes $r M S E$. However, no information is obtained regarding the uncertainty of this $\gamma_{\mathrm{f}}$. In order to overcome the uncertainty of 
the estimation of the $\gamma_{f}$, a bootstrap resampling technique is used in this study as described by Van Gent et al. (2007). A bootstrap resample is a random selection of $\mathrm{N}$ datum taken from the $\mathrm{N}$ original dataset, with the probability $1 / \mathrm{N}$ that a particular datum is selected each time. As a result, some data are selected once or more than once, while others may be absent in a resample.

In this study, 1000 resamples were made for each type of armor and overtopping predictor. For each resample, the $\gamma_{\mathrm{f}}$ was varied around the value given by Coeveld et al. (2005) and the rMSE was calculated for each $\gamma_{f}$. Thus, 1000 values for the roughness factor which minimized the IMSE were obtained and used to statistically characterize the $\gamma_{f}$ to be used for each type of armor and overtopping predictor. The $\gamma_{f}$ was characterized by the percentiles $10 \%\left(\gamma_{f 10}\right), 50 \%\left(\gamma_{f 50}\right)$ and $90 \%\left(\gamma_{f 90}\right)$ of the discrete histogram. The calculated-values of $\gamma_{f 10}, \gamma_{f 50}$ and $\gamma_{f 90}$ were used in combination with data given in Table 3 to obtain the expected rMSE presented in Table 4.

\subsection{General method: application to cubes (2L, random)}

Once the tests were selected from the CLASH database and the 1000 resamples were created by bootstrapping, each formula was applied to each resample to optimize the roughness factor. Fig. 5 shows the rMSE corresponding to different $\gamma_{f}$ for three specific resamples using the formula $Q_{V M J}$ (Eq. 1). Other formulas show similar graphs; each has a different $r M S E$ for a different value of $\gamma_{f}$. 


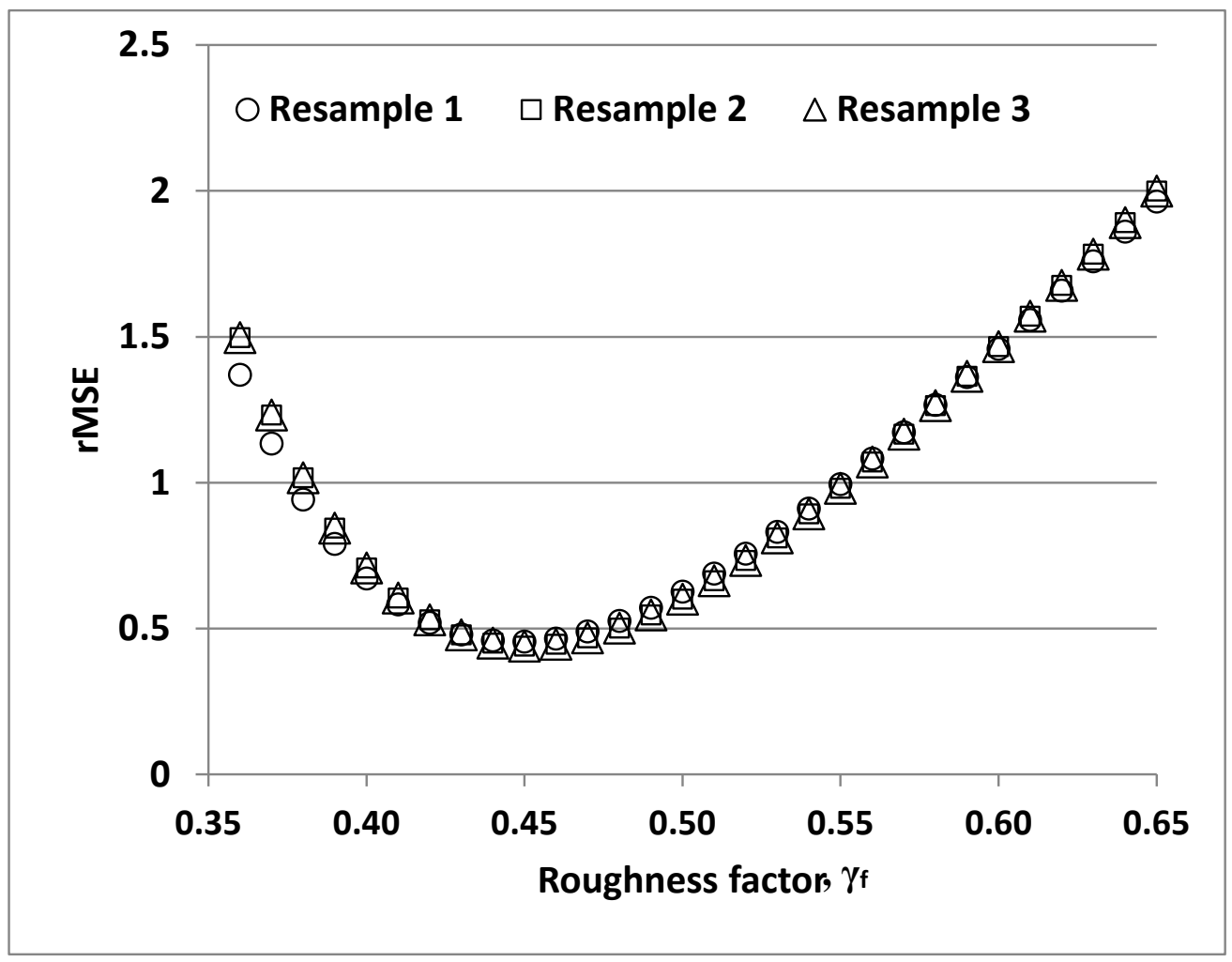

Figure 5. Roughness factor and rMSE for cube (2L, random) using $Q_{V M J}$.

Considering a specific overtopping predictor, the $\gamma_{\mathrm{f}}$ which minimized the $r M S E$ of each resample was used to define a discrete frequency histogram, characterized by the $10 \%$, 50\% and 90\% percentiles: $\gamma_{f 10}, \gamma_{f 50}$, and $\gamma_{f 90}$ (see Fig. 6). The $r M S E$ were calculated for at least 30 values of $\gamma_{f}$ around the $\gamma_{f}$ given by Coeveld et al (2005) in increments of 0.01 . In the case of cube ( $2 \mathrm{~L}$, random) and Eq. (1), $\gamma_{f 10}=0.44, \gamma_{f 50}=0.45$, and $\gamma_{f 90}=0.46$. Fig. 7 illustrates the cross-validation graph of the estimated overtopping using $Q_{V M}$ with $\gamma_{f 50}=0.45$ in comparison to the measured overtopping. 


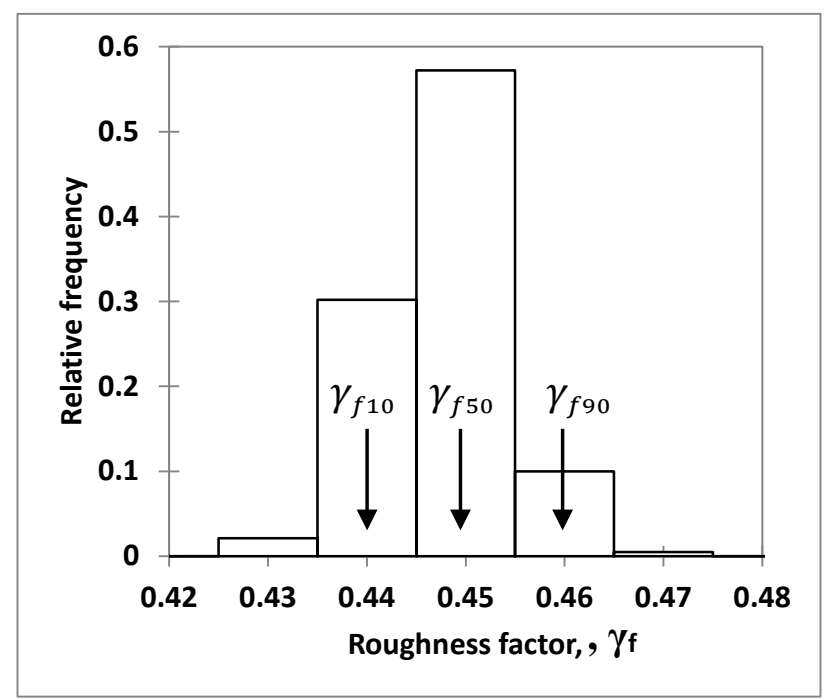

Figure 6. Roughness factor frequency histogram corresponding to cube ( $2 \mathrm{~L}$ random) using Eq. (1).

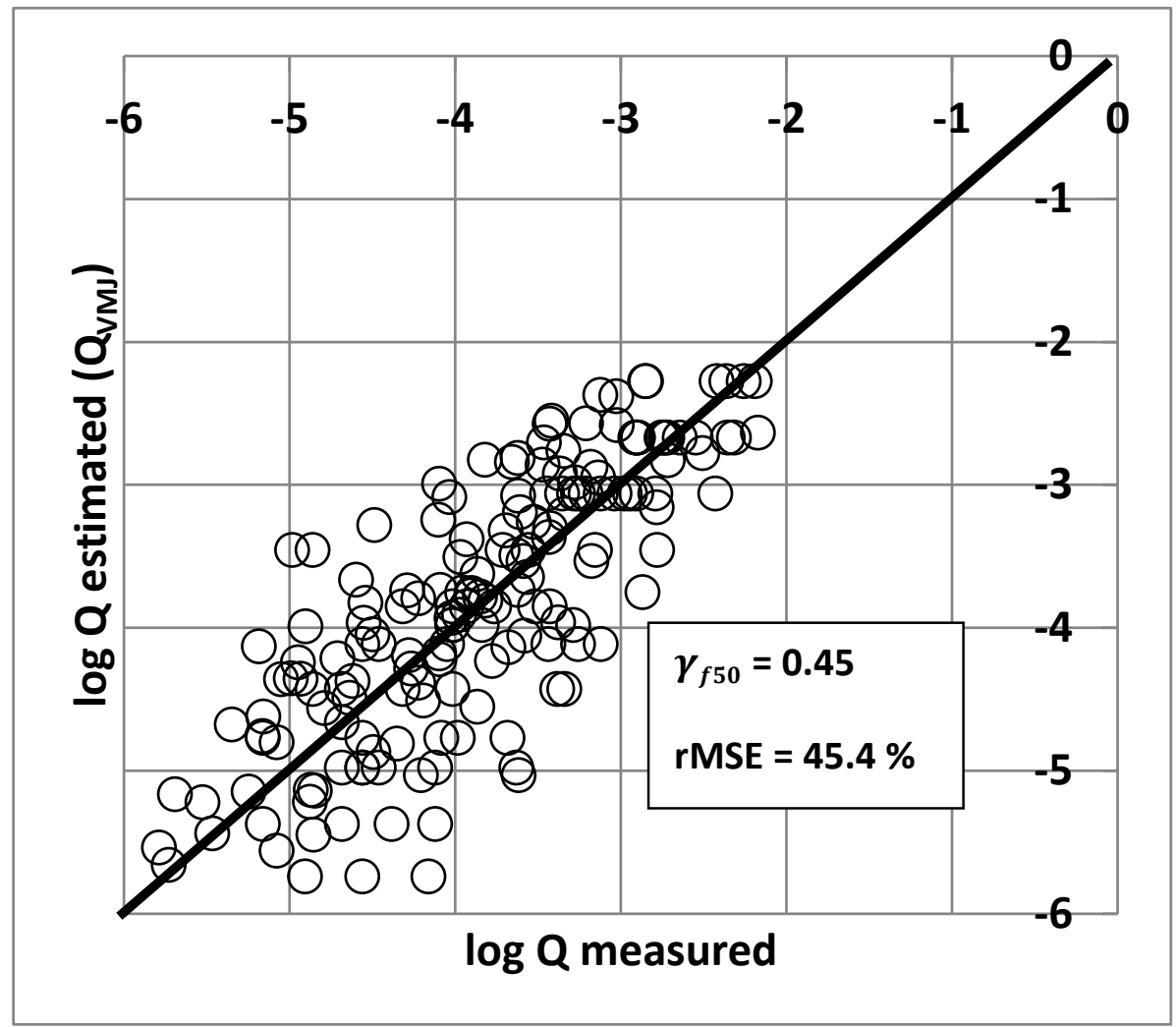

Figure 7. Measured and estimated overtopping rates of cube (2L random) using Eq. (1).

\section{Results}


Table 4 summarizes the results of $\gamma_{f 10}, \gamma_{f 50}$, and $\gamma_{f 90}$ as well as the associated rMSE for different armors. The CLNN gave the lowest rMSE for all cases except for Dolos, where a slightly lower rMSE for $\gamma_{f 50}$ was given by Smolka et al. (2009). For smooth slopes and estimator $Q_{C L N N,}$ no prediction is given if $\gamma_{f}>1.00$ because the $\gamma_{f}$-value is internally limited by the $C L N N$ to $0.30<\gamma_{f} \leq 1.00$. The first column shows the roughness factors proposed by Coeveld et al. (2005) used for the CLNN and the roughness factors calculated by Smolka et al. (2009) for Cubipod armors. Both studies found $\gamma_{f}=0.50$ for cube armors (2L, random).

Table 4 shows the variability of the optimum roughness factor for each type of armor and formula. There is a range of roughness factors which leads to almost the same rMSE (see Fig. 5) for each concrete armor unit. Therefore, the roughness factors shown in Table 4 may change in the future if additional tests are added to the dataset used for calibration.

The selected overtopping formulas clearly improved their prediction when increasing the number of variables, except Eq. (4) which gives less accurate predictions than Eq. (1) in most cases. One should take into consideration that selected CLASH tests for calibration (see Table 3) have $0.5<R_{c} / H_{m 0}<3.5$; therefore, using Eq. (4) does not take advantage of its better performance for zero and low crest freeboard cases. 


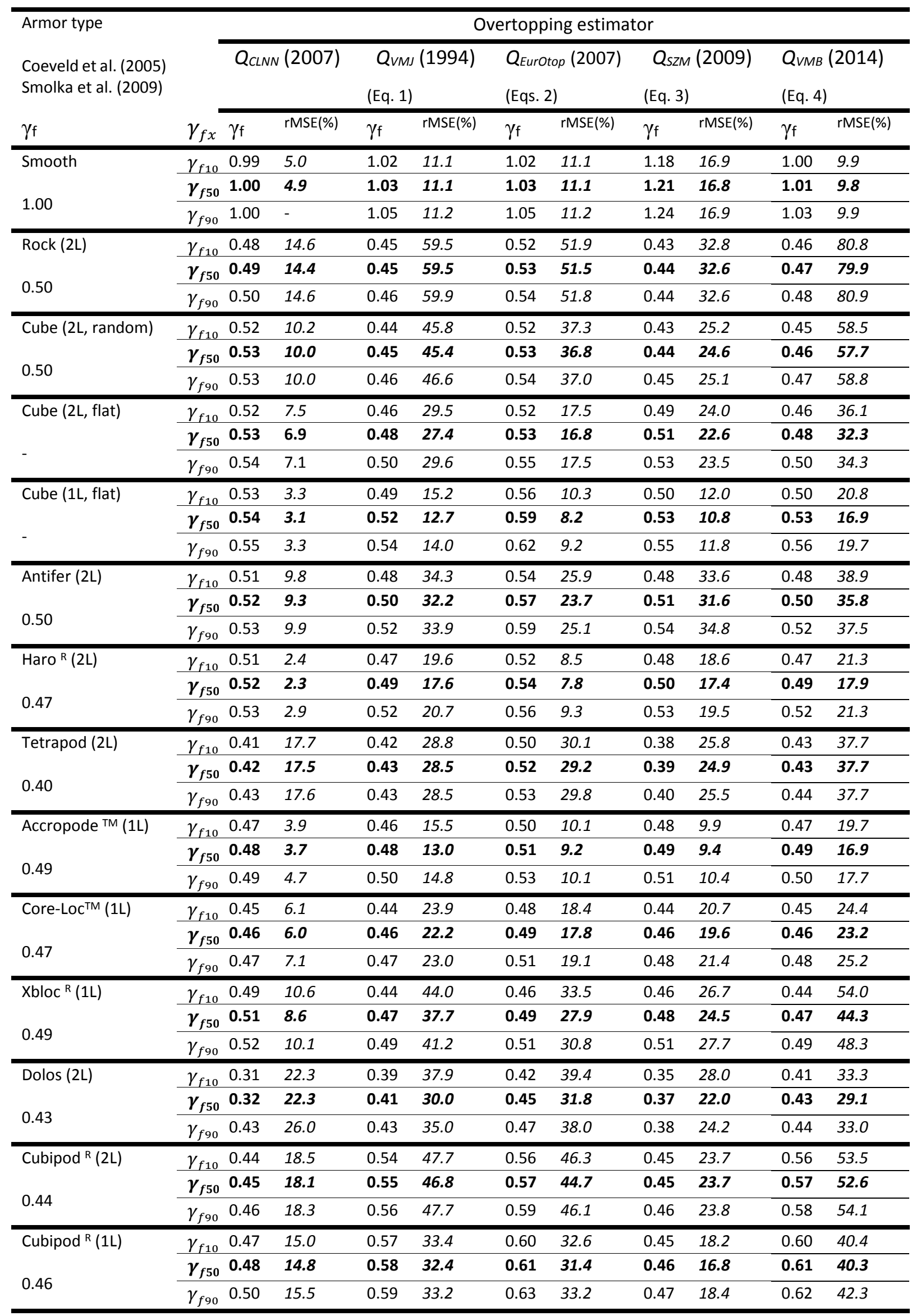

Table 4. Roughness factors and rMSE (CLASH database and Tables 6 and 7). 
The CLNN shows the minimum rMSE in this study and avoids the influence of certain structural variables on the estimation of the roughness factor. Thus, the CLNN is recommended to compare the influence of a given type of armor on overtopping discharges with different cross sections. Simple formulas such as those given by EurOtop (2007) can be applied considering the wave conditions and structural geometry which have been used to obtain the roughness factors.

The armor placement did not significantly influence the overtopping discharges on cube armors. This result is consistent with the conclusions drawn by Bruce et al. (2009), and may change in the future when increasing the number of data for $2 \mathrm{~L}$-flat cubes $(28$ in this study) to be compared with the 171 tests of 2 L-random cubes. Cubes and Cubipods were analyzed in single- and double- layer armors. In both cases, the single-layer system presented higher roughness factors, and hence higher overtopping discharges are expected.

Only eight tests using Dolos conducted by Pedersen (1996) were selected from CLASH database $(\cot \alpha=2.5)$ with small overtopping discharges. Thus, variations in the roughness factors for Dolos listed in Table 4 are expected when more overtopping data are included.

Single- and double-layer Cubipod ${ }^{\mathrm{R}}$ armors were tested with $A_{c} / R_{c}<1$; therefore, Eq. (1), Eqs. (2) and Eq. (4) which do not include $A_{c}$ as input variable give unrealistic values of $\gamma_{f}$ for Cubipod ${ }^{\mathrm{R}}$ armors compared to those given by CLNN and Eq. (3), which include $A_{c} / R_{c}$ as an input variable. Thus, the formula in Smolka et al. (2009) or the CLNN are 
recommended to properly estimate wave overtopping on Cubipod ${ }^{R}$ armored breakwaters.

Table 5 summarizes the minimum and maximum roughness factors for each type of armor listed in Table 1 and the percentiles 10\% and 90\% of the calculated-roughness factors in this study to be used in the CLNN. While the ranges of the $\gamma_{f}$ extracted from the literature are broad and usually do not reflect the influence on deviations of the $\gamma_{\mathrm{f}}$, the ranges of the calculated- $\gamma_{f}$ for the CLNN were quantified here using bootstrapping technique. In the case of Dolos, only 8 tests (Pedersen, 1996) were selected from the CLASH database; more data would be useful to increase the representativeness of the $\gamma_{\mathrm{f}}$ derived in this study.

\begin{tabular}{|c|c|c|}
\hline \multirow{2}{*}{ Type of armor } & Taken from Table 1 & $Q_{\text {CLNN }}(2007)$ \\
\hline & $\operatorname{Min}\left(\gamma_{f}\right)-\operatorname{Max}\left(\gamma_{f}\right)$ & $\gamma_{f 10}, \gamma_{f 90}$ \\
\hline Smooth & $1.00,1.00$ & $0.99,1.00$ \\
\hline Rock (2L) & $0.40,0.60$ & $0.48,0.50$ \\
\hline Cube (2L, random) & $0.47,0.50$ & $0.52,0.53$ \\
\hline Cube (2L, flat) & 0.47 & $0.52,0.54$ \\
\hline Cube (1L, flat) & $0.49,0.50$ & $0.53,0.55$ \\
\hline Antifer (2L) & $0.47,0.65$ & $0.51,0.53$ \\
\hline $\operatorname{Haro}^{\mathrm{R}}(2 \mathrm{~L})$ & $0.47,0.63$ & $0.51,0.53$ \\
\hline Tetrapod (2L) & $0.38,0.40$ & $0.41,0.43$ \\
\hline Accropode (1L) & $0.44,0.55$ & $0.47,0.49$ \\
\hline Core-Loc ${ }^{\mathrm{TM}}(1 \mathrm{~L})$ & $0.44,0.47$ & $0.45,0.47$ \\
\hline $\mathrm{Xbloc}^{\mathrm{R}}(1 \mathrm{~L})$ & $0.44,0.49$ & $0.49,0.52$ \\
\hline Dolos (2L) & $0.43,0.45$ & $0.31,0.43$ \\
\hline Cubipod $^{R}(2 \mathrm{~L})$ & 0.44 & $0.44,0.46$ \\
\hline
\end{tabular}


Table 5. Range of roughness factors for each type of armor.

\subsection{Influence of packing density and armor roughness on overtopping}

None of the overtopping formulas given in the literature explicitly introduces armor porosity or packing density as an input variable. In this study, test data reported by Pearson et al. (2004) were selected from the CLASH database for all types of armor except Dolos and Cubipods. Thus, packing densities given by Pearson et al. (2004), which are the same as those considered by Bruce et al. (2006), were assumed here to represent the selected data of the different types of armor. For Dolos armors, Pedersen's (1996) overtopping data were used here but this author did not provide the packing density. For Cubipod tests, packing densities were taken from Smolka et al. (2009).

The $\gamma_{f 50}$-calibrated roughness factors from the CLNN were used here to study the influence of packing density $(\phi)$ and armor roughness $\left(\gamma_{f}\right)$ on overtopping, given that the CLNN showed the lowest rMSE. Fig. 8 illustrates the influence of armor porosity $(p=1-\phi / n)$ on the roughness factor. The armor porosities used here are the recommended values for each type of armor unit. In both single- and double-layer armors, armor units placed with higher porosity tend to have a lower roughness factor. Given an armor unit, an armor porosity above recommended values decreases the concrete consumption but also decreases the hydraulic stability (see Medina et al., 2014), affecting the breakwater performance during lifetime.

The straight line drawn in Fig. 8 represents the influence of armor porosity on the roughness factor without considering the armor unit geometry or number of layers. The 
linear model $\gamma_{f}=1-1.25 p$ shown in Fig. 8 fits reasonably well all cases (CV $\left.=\left|\gamma_{f-} \gamma_{f 50}\right| / \gamma_{f}<15 \%\right)$ except the double-layer rock armor which has a lower than expected roughness factor.

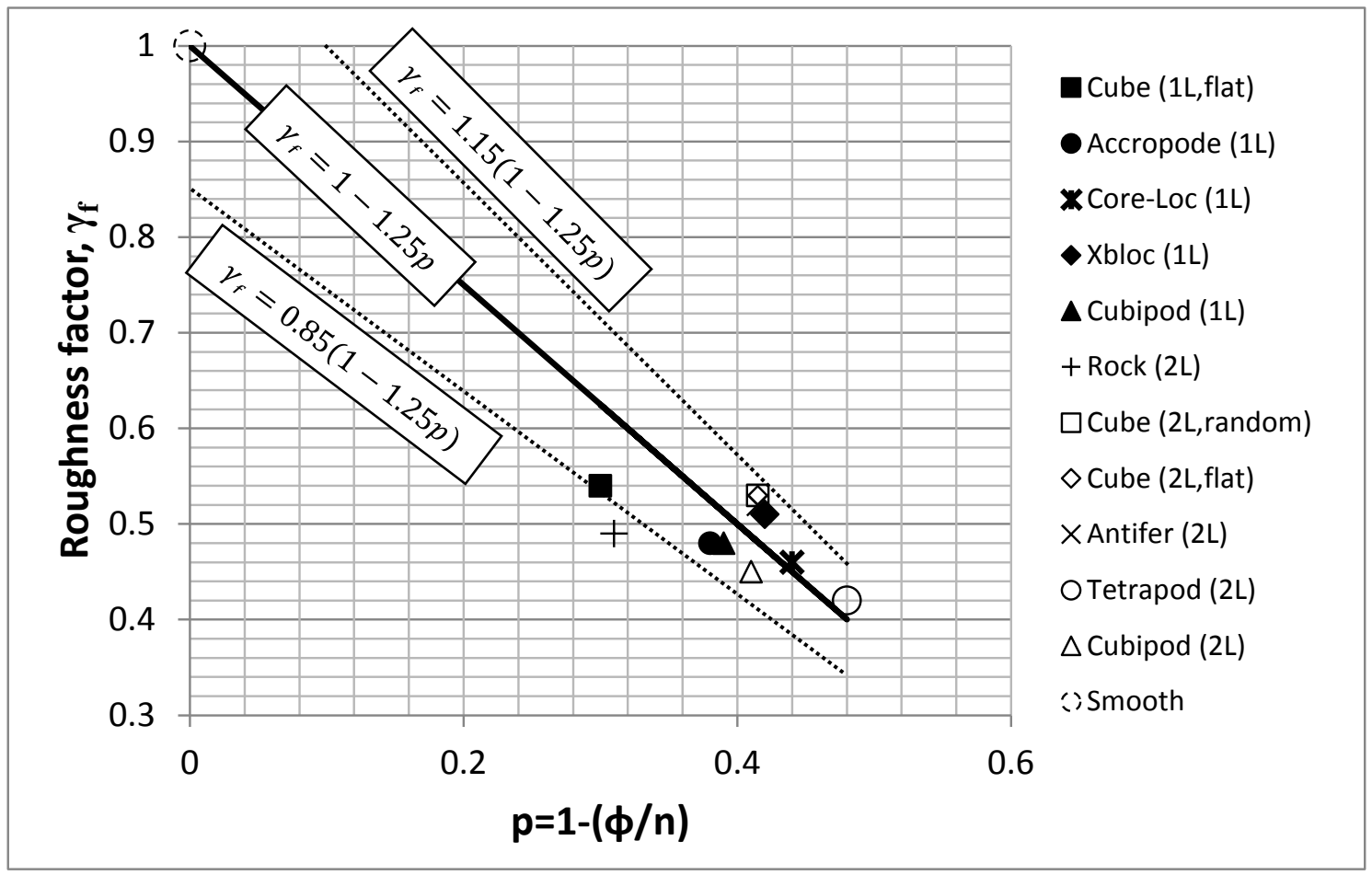

Figure 8. $\gamma_{f 50}$-calibrated roughness factors of the CLNN and armor porosity.

For practical design applications, the $\gamma_{f 50}$-calibrated roughness factors given in Table 4 can be used together with their associated formula to estimate wave overtopping discharges on mound breakwaters. The best estimations are given by $Q_{C L N N}(2007)$. Armor porosity affects not only armor roughness and overtopping, but also armor hydraulic stability; recommended packing densities must be followed to avoid changes in porosity during lifetime. Designing an armor with porosity higher than the recommended values may decrease the roughness factors and the economic cost. However, in these cases, significant settlements are expected during lifetime, thus 
changing the initial armor porosity affecting the armor stability and increasing estimated overtopping rates.

\subsection{Sensitivity of overtopping rates depending on the roughness factor}

An analytical study of the influence of small variations of the roughness factor on overtopping is discussed in this section. Only formulas with a topology similar to that of Eq. (1) and Eq. (3) are considered here to analytically compare the different variables involved in the overtopping process. Eq. (6) summarizes the partial derivative of the formulas $Q_{V M J}$ (Eq. 1) and $Q_{S Z M}$ (Eq. 3).

$$
\frac{\partial Q_{e}}{\partial \gamma_{f}}=-K\left(\frac{R_{C}}{H_{m 0}}\right) Q_{e}\left(-\frac{1}{\gamma_{f}^{2}}\right)
$$

where $\mathrm{K}$ is a positive constant, and $Q_{e}=q_{e} / \sqrt{g H_{m 0}^{3}}$ is the estimated dimensionless overtopping rate. Eq. (6) can be rewritten as:

$$
\frac{\partial Q_{e}}{Q_{e}}=\left(\frac{\partial \gamma_{f}}{\gamma_{f}}\right)\left(\frac{K}{\gamma_{f}}\right)\left(\frac{R_{C}}{H_{m 0}}\right)
$$

Considering Eq. (1) and (7), a slight variation in the roughness factor, say $\Delta \gamma_{f} / \gamma_{f}=$ $+0.01 / 0.50=+2 \%$, generates a $15 \%$ increase in the estimated overtopping rates with $R_{c} / H_{m 0}=1.5$. For lower values of $R_{c} / H_{m 0}$, overtopping rates are less sensitive to variations in the roughness factor. Thus, the relative crest freeboard, $R_{c} / H_{m 0}$, affects the sensitivity of overtopping to variations in the roughness factor; the higher the $R_{d} / H_{m o}$, the greater the influence of variations in $\gamma_{f}$ on the estimated overtopping discharges. The values of $\gamma_{f 10}, \gamma_{f 50}$, and $\gamma_{f 90}$ shown in Table 4 indicate that overtopping estimations using $\gamma_{f 50}$ may 
easily change in the future from $10 \%$ to $25 \%$ if the dataset is significantly enlarged with additional tests.

The relative increases in overtopping rates, $\Delta Q / Q_{e}$, are directly proportional to the relative increase in the roughness factor, $\Delta \gamma_{f} / \gamma_{f}$, the relative crest freeboard, $R_{c} / H_{m 0}$, and indirectly proportional to the roughness factor, $\gamma_{f}$.

\section{Conclusions}

This paper describes a methodology to estimate the optimum value of the roughness factor to be used in a specific overtopping estimator and a given overtopping dataset. This methodology was applied to four empirical formulas and a neural network tool to estimate mean overtopping discharges ( $Q_{V M J}, Q_{\text {EurOtop, }} Q_{S Z M}$ and $\left.Q_{C L N N}\right)$ of conventional mound breakwaters. The median values of the roughness factor $\left(\gamma_{f 50}\right)$ given in Table 4 are suitable to estimate the mean overtopping discharges. The present methodology can be applied to properly estimate the $\gamma_{f}$ to be used in new formulas which include the roughness factor as an input variable to estimate wave overtopping.

Simple overtopping formulas with fewer input variables are easy to use but more information is implicitly absorbed by the roughness factor. In the preliminary design stage, formulas with a few variables such that given by Eq. (1) can be applied considering the wave conditions and the structural variables used to obtain the roughness factors. The $\gamma_{f}$ is highly dependent on the corresponding formula and the dataset used for calibration. For instance, single- and double-layer Cubipod ${ }^{R}$ armors (Smolka et al., 2009) were tested with $A_{c} / R_{c}<1$; therefore, Eq. (1), Eqs. (2) and Eq. (4), which do not include $A_{c}$ as input variable, give unrealistic values of $\gamma_{f}$ for Cubipod ${ }^{R}$ armors compared to those 
given by CLNN and Eq. (3), which include $A_{c} / R_{c}$ as an input variable. The formula proposed by Smolka et al. (2009) or the CLNN are recommended here to estimate overtopping discharges on Cubipod ${ }^{R}$ armors. Very low and disperse values of roughness factor were obtained for Dolos armors because of the low number of Dolos results in the database; significant changes in Dolos roughness factors are expected when more overtopping data are available to be used for calibration.

The EurOtop (2007) overtopping predictor given by Eqs. (2) requires increasing the roughness factor given by Bruce et al. (2006) to effectively improve the mean overtopping prediction reducing rMSE. Generally speaking, the formula by Van der Meer and Bruce (2014) gave slightly higher rMSE than Eq. (1) in the range of data used in this study $\left(0.5<R_{c} / H_{m 0}<3.5\right)$ which do not include zero and low crest freeboard cases.

The roughness factors given in Table 4 correspond to armors with characteristics described in Table 3. Cubes and Cubipods were analyzed in single- and double-layer armors: one layer systems presented higher roughness factors and hence higher overtopping discharges. At first sight, higher armor porosity $(p=1-\phi / n)$ leads to a lower roughness factor but also to a lower hydraulic stability and a higher risk of settlements during lifetime. Designing an armor with porosity above the recommended values will tend to generate settlements during lifetime, thus decreasing the initial armor porosity, changing the roughness factor and increasing overtopping rates. Thus, each type of armor must be designed and constructed with its recommended armor porosity and placement technique to maintain the reliability of the overtopping estimations. 
The values of $\gamma_{f 10}, \gamma_{f 50}$, and $\gamma_{f 90}$ given in Table 4 indicate that overtopping estimations using $\gamma_{f 50}$ may easily change in the future from $10 \%$ to $25 \%$ if the dataset is significantly enlarged with additional tests. The relative crest freeboard $\left(R_{c} / H_{m 0}\right)$ affects the sensitivity of overtopping estimations to variations in the roughness factor; the higher the $R_{c} / H_{m 0}$, the higher the influence of the increase in $\gamma_{f}$ on the estimated overtopping discharges.

When comparing the influence of a concrete armor unit on overtopping discharges with different cross sections, estimator $Q_{C L N N}$ is recommended. $Q_{C L N N}$ shows the minimum rMSE in this study and eliminates the influence of certain structural variables on the estimation of the roughness factor, not included in other formulas. To avoid misunderstandings, the experimental database and the roughness factor should be clearly specified when new overtopping formulas are published.

\section{Acknowledgments}

The authors are grateful for financial support from European FEDER and Spanish Ministerio de Economía y Competitividad (Grant BIA2012-33967), SATO (OHL Group) and CDTI (Centro para el Desarrollo Tecnológico e Industrial). The first author was funded through the FPU program (Formación del Profesorado Universitario, Grant AP2010-4366) by the Spanish Ministerio de Educación, Cultura y Deporte. The authors also thank Debra Westall for revising the manuscript.

Appendix A. Small-scale tests reported by Smolka et al. (2009)

\begin{tabular}{|c|c|c|c|c|c|c|c|}
\hline $\mathrm{h}[\mathrm{m}]$ & $\mathrm{H}_{\mathrm{m} 0 \text { toe }}[\mathrm{m}]$ & $T_{p}[s]$ & $\mathrm{T}_{\mathrm{m}-1,0 \text { toe }}[\mathrm{s}]$ & $h_{t}[\mathrm{~m}]$ & $\mathbf{R}_{\mathrm{c}}[\mathrm{m}]$ & $A_{c}[m]$ & $q\left(\mathrm{~m}^{3} / \mathrm{s} / \mathrm{m}\right)$ \\
\hline 0.550 & 0.132 & 2.968 & 2.628 & 0.550 & 0.203 & 0.150 & $1.28 \mathrm{E}-04$ \\
\hline 0.550 & 0.135 & 3.103 & 2.640 & 0.550 & 0.203 & 0.150 & $1.23 \mathrm{E}-04$ \\
\hline
\end{tabular}




\begin{tabular}{|c|c|c|c|c|c|c|c|}
\hline 0.500 & 0.138 & 3.103 & 2.780 & 0.500 & 0.253 & 0.200 & $1.20 \mathrm{E}-04$ \\
\hline 0.550 & 0.135 & 3.103 & 2.647 & 0.550 & 0.263 & 0.150 & 4.87E-05 \\
\hline 0.550 & 0.125 & 2.968 & 2.530 & 0.550 & 0.203 & 0.150 & $4.63 \mathrm{E}-05$ \\
\hline 0.550 & 0.116 & 2.968 & 2.459 & 0.550 & 0.203 & 0.150 & $3.50 \mathrm{E}-05$ \\
\hline 0.550 & 0.144 & 2.528 & 1.942 & 0.550 & 0.203 & 0.150 & $3.46 \mathrm{E}-05$ \\
\hline 0.550 & 0.130 & 2.528 & 2.206 & 0.550 & 0.203 & 0.150 & $3.44 \mathrm{E}-05$ \\
\hline 0.550 & 0.138 & 1.932 & 1.814 & 0.550 & 0.203 & 0.150 & $3.27 \mathrm{E}-05$ \\
\hline 0.550 & 0.137 & 2.528 & 2.321 & 0.550 & 0.203 & 0.150 & $3.05 \mathrm{E}-05$ \\
\hline 0.550 & 0.137 & 1.693 & 1.693 & 0.550 & 0.203 & 0.150 & $2.53 \mathrm{E}-05$ \\
\hline 0.550 & 0.137 & 2.028 & 1.871 & 0.550 & 0.203 & 0.150 & $2.26 \mathrm{E}-05$ \\
\hline 0.500 & 0.131 & 3.103 & 2.555 & 0.500 & 0.253 & 0.200 & $2.16 \mathrm{E}-05$ \\
\hline 0.550 & 0.116 & 2.498 & 2.420 & 0.550 & 0.203 & 0.150 & $2.10 \mathrm{E}-05$ \\
\hline 0.550 & 0.126 & 2.528 & 2.130 & 0.550 & 0.203 & 0.150 & $1.86 \mathrm{E}-05$ \\
\hline 0.550 & 0.131 & 1.693 & 1.693 & 0.550 & 0.203 & 0.150 & $1.86 \mathrm{E}-05$ \\
\hline 0.550 & 0.155 & 2.276 & 2.040 & 0.550 & 0.263 & 0.150 & $1.69 \mathrm{E}-05$ \\
\hline 0.500 & 0.151 & 2.276 & 2.002 & 0.500 & 0.253 & 0.200 & $1.65 \mathrm{E}-05$ \\
\hline 0.550 & 0.138 & 1.304 & 1.305 & 0.550 & 0.203 & 0.150 & $1.22 \mathrm{E}-05$ \\
\hline 0.550 & 0.128 & 1.205 & 1.183 & 0.550 & 0.203 & 0.150 & $1.21 \mathrm{E}-05$ \\
\hline 0.550 & 0.131 & 2.028 & 1.773 & 0.550 & 0.203 & 0.150 & $1.15 \mathrm{E}-05$ \\
\hline 0.550 & 0.108 & 2.968 & 2.320 & 0.550 & 0.203 & 0.150 & $1.10 \mathrm{E}-05$ \\
\hline 0.550 & 0.157 & 1.330 & 1.313 & 0.550 & 0.263 & 0.150 & $1.06 \mathrm{E}-05$ \\
\hline 0.550 & 0.131 & 1.796 & 1.750 & 0.550 & 0.203 & 0.150 & $9.53 \mathrm{E}-06$ \\
\hline 0.550 & 0.125 & 1.588 & 1.588 & 0.550 & 0.203 & 0.150 & $9.00 \mathrm{E}-06$ \\
\hline 0.550 & 0.125 & 3.103 & 2.541 & 0.550 & 0.263 & 0.150 & $8.48 \mathrm{E}-06$ \\
\hline 0.550 & 0.144 & 2.090 & 1.886 & 0.550 & 0.263 & 0.150 & $8.34 \mathrm{E}-06$ \\
\hline 0.550 & 0.117 & 1.812 & 1.617 & 0.550 & 0.203 & 0.150 & $8.21 \mathrm{E}-06$ \\
\hline 0.550 & 0.135 & 1.412 & 1.262 & 0.550 & 0.203 & 0.150 & $8.08 \mathrm{E}-06$ \\
\hline 0.550 & 0.121 & 1.812 & 1.693 & 0.550 & 0.203 & 0.150 & 5.60E-06 \\
\hline 0.550 & 0.114 & 1.679 & 1.581 & 0.550 & 0.203 & 0.150 & $5.23 \mathrm{E}-06$ \\
\hline 0.550 & 0.114 & 1.151 & 1.112 & 0.550 & 0.203 & 0.150 & $4.48 \mathrm{E}-06$ \\
\hline 0.500 & 0.138 & 2.090 & 1.855 & 0.500 & 0.253 & 0.200 & 4.03E-06 \\
\hline 0.550 & 0.127 & 1.339 & 1.236 & 0.550 & 0.203 & 0.150 & $4.02 \mathrm{E}-06$ \\
\hline 0.500 & 0.142 & 1.330 & 1.247 & 0.500 & 0.253 & 0.200 & $3.89 \mathrm{E}-06$ \\
\hline 0.550 & 0.118 & 1.495 & 1.495 & 0.550 & 0.203 & 0.150 & $3.50 \mathrm{E}-06$ \\
\hline 0.500 & 0.106 & 2.498 & 2.342 & 0.500 & 0.253 & 0.200 & $3.22 \mathrm{E}-06$ \\
\hline 0.550 & 0.146 & 1.264 & 1.248 & 0.550 & 0.263 & 0.150 & 3.19E-06 \\
\hline 0.550 & 0.111 & 1.495 & 1.310 & 0.550 & 0.203 & 0.150 & $2.95 \mathrm{E}-06$ \\
\hline 0.550 & 0.120 & 1.241 & 1.197 & 0.550 & 0.203 & 0.150 & $2.64 \mathrm{E}-06$ \\
\hline 0.550 & 0.131 & 1.205 & 1.181 & 0.550 & 0.263 & 0.150 & $2.29 \mathrm{E}-06$ \\
\hline 0.550 & 0.110 & 2.498 & 2.271 & 0.550 & 0.263 & 0.150 & $2.18 \mathrm{E}-06$ \\
\hline 0.500 & 0.135 & 1.264 & 1.221 & 0.500 & 0.253 & 0.200 & $2.03 E-06$ \\
\hline 0.550 & 0.114 & 2.528 & 2.019 & 0.550 & 0.203 & 0.150 & $1.50 \mathrm{E}-06$ \\
\hline 0.550 & 0.100 & 1.484 & 1.423 & 0.550 & 0.203 & 0.150 & $1.08 \mathrm{E}-06$ \\
\hline 0.550 & 0.105 & 1.304 & 1.248 & 0.550 & 0.203 & 0.150 & $9.41 \mathrm{E}-07$ \\
\hline 0.550 & 0.117 & 1.151 & 1.112 & 0.550 & 0.263 & 0.150 & $9.24 \mathrm{E}-07$ \\
\hline 0.550 & 0.108 & 1.131 & 1.119 & 0.550 & 0.203 & 0.150 & $9.05 E-07$ \\
\hline 0.550 & 0.100 & 1.056 & 1.048 & 0.550 & 0.203 & 0.150 & $8.85 \mathrm{E}-07$ \\
\hline 0.500 & 0.123 & 1.932 & 1.706 & 0.500 & 0.253 & 0.200 & $8.46 \mathrm{E}-07$ \\
\hline 0.550 & 0.114 & 1.157 & 1.157 & 0.550 & 0.203 & 0.150 & 8.27E-07 \\
\hline 0.550 & 0.097 & 1.304 & 1.197 & 0.550 & 0.203 & 0.150 & 7.10E-07 \\
\hline 0.550 & 0.110 & 1.101 & 1.073 & 0.550 & 0.263 & 0.150 & $7.04 \mathrm{E}-07$ \\
\hline 0.550 & 0.107 & 1.693 & 1.527 & 0.550 & 0.203 & 0.150 & $6.83 \mathrm{E}-07$ \\
\hline 0.550 & 0.097 & 2.498 & 2.183 & 0.550 & 0.203 & 0.150 & $5.89 \mathrm{E}-07$ \\
\hline 0.500 & 0.122 & 1.151 & 1.153 & 0.500 & 0.253 & 0.200 & $4.69 \mathrm{E}-07$ \\
\hline 0.550 & 0.101 & 1.061 & 1.088 & 0.550 & 0.203 & 0.150 & 4.17E-07 \\
\hline 0.550 & 0.130 & 1.796 & 1.757 & 0.550 & 0.263 & 0.150 & $3.83 \mathrm{E}-07$ \\
\hline 0.550 & 0.107 & 2.028 & 1.914 & 0.550 & 0.203 & 0.150 & $3.83 \mathrm{E}-07$ \\
\hline 0.550 & 0.116 & 1.679 & 1.580 & 0.550 & 0.263 & 0.150 & $3.25 \mathrm{E}-07$ \\
\hline 0.500 & 0.107 & 1.101 & 1.081 & 0.500 & 0.253 & 0.200 & $2.51 \mathrm{E}-07$ \\
\hline 0.550 & 0.099 & 1.693 & 1.453 & 0.550 & 0.203 & 0.150 & $1.80 \mathrm{E}-07$ \\
\hline
\end{tabular}




\begin{tabular}{llllllll}
0.550 & 0.101 & 1.484 & 1.423 & 0.550 & 0.263 & 0.150 & $1.80 \mathrm{E}-07$ \\
0.550 & 0.102 & 1.056 & 1.045 & 0.550 & 0.263 & 0.150 & $1.56 \mathrm{E}-07$ \\
0.550 & 0.089 & 1.339 & 1.159 & 0.550 & 0.203 & 0.150 & $1.40 \mathrm{E}-07$ \\
\hline
\end{tabular}

Table 6. Cubipod 2L small-scale tests by Smolka et al. (2009).

\begin{tabular}{|c|c|c|c|c|c|c|c|}
\hline$h[\mathrm{~m}]$ & $\mathrm{H}_{\mathrm{m} 0}$ toe $[\mathrm{m}]$ & $T_{p}[s]$ & $T_{m-1,0 \text { toe }}[\mathrm{s}]$ & $h_{t}[\mathrm{~m}]$ & $\mathbf{R}_{\mathrm{c}}[\mathrm{m}]$ & $A_{c}[m]$ & $q\left(m^{3} / \mathrm{s} / \mathrm{m}\right)$ \\
\hline 0.500 & 0.100 & 1.061 & 1.048 & 0.500 & 0.253 & 0.160 & $2.60 \mathrm{E}-07$ \\
\hline 0.500 & 0.116 & 1.131 & 1.116 & 0.500 & 0.253 & 0.160 & $5.81 \mathrm{E}-07$ \\
\hline 0.500 & 0.129 & 1.212 & 1.191 & 0.500 & 0.253 & 0.160 & $1.54 \mathrm{E}-06$ \\
\hline 0.500 & 0.133 & 1.241 & 1.223 & 0.500 & 0.253 & 0.160 & $2.38 \mathrm{E}-06$ \\
\hline 0.500 & 0.141 & 1.304 & 1.247 & 0.500 & 0.253 & 0.160 & 5.69E-06 \\
\hline 0.500 & 0.093 & 1.452 & 1.372 & 0.500 & 0.253 & 0.160 & $1.13 \mathrm{E}-07$ \\
\hline 0.500 & 0.107 & 1.638 & 1.540 & 0.500 & 0.253 & 0.160 & $3.35 \mathrm{E}-07$ \\
\hline 0.500 & 0.122 & 1.879 & 1.704 & 0.500 & 0.253 & 0.160 & $1.30 \mathrm{E}-06$ \\
\hline 0.500 & 0.141 & 2.028 & 1.858 & 0.500 & 0.253 & 0.160 & $1.00 \mathrm{E}-05$ \\
\hline 0.500 & 0.152 & 2.301 & 1.994 & 0.500 & 0.253 & 0.160 & $2.51 \mathrm{E}-05$ \\
\hline 0.500 & 0.158 & 2.301 & 2.055 & 0.500 & 0.253 & 0.160 & $3.85 \mathrm{E}-05$ \\
\hline 0.500 & 0.114 & 2.660 & 2.330 & 0.500 & 0.253 & 0.160 & $5.60 \mathrm{E}-06$ \\
\hline 0.500 & 0.132 & 3.151 & 2.547 & 0.500 & 0.253 & 0.160 & 2.61E-05 \\
\hline 0.550 & 0.086 & 0.962 & 0.978 & 0.550 & 0.203 & 0.110 & $1.12 \mathrm{E}-07$ \\
\hline 0.550 & 0.094 & 0.999 & 1.010 & 0.550 & 0.203 & 0.110 & $5.40 \mathrm{E}-07$ \\
\hline 0.550 & 0.099 & 1.061 & 1.049 & 0.550 & 0.203 & 0.110 & $1.56 \mathrm{E}-06$ \\
\hline 0.550 & 0.108 & 1.084 & 1.076 & 0.550 & 0.203 & 0.110 & $2.72 \mathrm{E}-06$ \\
\hline 0.550 & 0.115 & 1.157 & 1.114 & 0.550 & 0.203 & 0.110 & 4.62E-06 \\
\hline 0.550 & 0.091 & 1.157 & 1.117 & 0.550 & 0.203 & 0.110 & $3.75 \mathrm{E}-07$ \\
\hline 0.550 & 0.099 & 1.212 & 1.170 & 0.550 & 0.203 & 0.110 & $1.52 \mathrm{E}-06$ \\
\hline 0.550 & 0.107 & 1.241 & 1.218 & 0.550 & 0.203 & 0.110 & 3.07E-06 \\
\hline 0.550 & 0.113 & 1.339 & 1.270 & 0.550 & 0.203 & 0.110 & $3.51 \mathrm{E}-06$ \\
\hline 0.550 & 0.120 & 1.412 & 1.321 & 0.550 & 0.203 & 0.110 & $1.05 \mathrm{E}-05$ \\
\hline 0.550 & 0.128 & 1.495 & 1.375 & 0.550 & 0.203 & 0.110 & $2.14 \mathrm{E}-05$ \\
\hline 0.550 & 0.135 & 1.495 & 1.431 & 0.550 & 0.203 & 0.110 & 2.97E-05 \\
\hline 0.550 & 0.143 & 1.588 & 1.480 & 0.550 & 0.203 & 0.110 & 4.38E-05 \\
\hline 0.550 & 0.084 & 1.304 & 1.275 & 0.550 & 0.203 & 0.110 & 8.06E-08 \\
\hline 0.550 & 0.094 & 1.495 & 1.354 & 0.550 & 0.203 & 0.110 & $1.22 \mathrm{E}-06$ \\
\hline 0.550 & 0.102 & 1.495 & 1.425 & 0.550 & 0.203 & 0.110 & $1.48 \mathrm{E}-06$ \\
\hline 0.550 & 0.109 & 1.693 & 1.509 & 0.550 & 0.203 & 0.110 & $5.08 \mathrm{E}-06$ \\
\hline 0.550 & 0.116 & 1.693 & 1.583 & 0.550 & 0.203 & 0.110 & $7.82 \mathrm{E}-06$ \\
\hline 0.550 & 0.126 & 1.693 & 1.657 & 0.550 & 0.203 & 0.110 & $7.02 \mathrm{E}-06$ \\
\hline 0.550 & 0.131 & 1.879 & 1.743 & 0.550 & 0.203 & 0.110 & $1.63 \mathrm{E}-05$ \\
\hline 0.550 & 0.138 & 2.028 & 1.810 & 0.550 & 0.203 & 0.110 & $3.10 \mathrm{E}-05$ \\
\hline 0.550 & 0.075 & 1.588 & 1.442 & 0.550 & 0.203 & 0.110 & 7.11E-08 \\
\hline 0.550 & 0.100 & 1.879 & 1.769 & 0.550 & 0.203 & 0.110 & $2.90 \mathrm{E}-07$ \\
\hline 0.550 & 0.107 & 2.028 & 1.857 & 0.550 & 0.203 & 0.110 & $2.30 \mathrm{E}-06$ \\
\hline 0.550 & 0.116 & 2.028 & 1.973 & 0.550 & 0.203 & 0.110 & $9.52 \mathrm{E}-06$ \\
\hline 0.550 & 0.134 & 2.528 & 2.191 & 0.550 & 0.203 & 0.110 & $2.86 \mathrm{E}-05$ \\
\hline 0.550 & 0.099 & 2.528 & 2.174 & 0.550 & 0.203 & 0.110 & $5.02 \mathrm{E}-06$ \\
\hline 0.550 & 0.120 & 2.528 & 2.406 & 0.550 & 0.203 & 0.110 & $5.15 \mathrm{E}-05$ \\
\hline 0.550 & 0.094 & 0.975 & 1.008 & 0.550 & 0.263 & 0.110 & 2.16E-07 \\
\hline 0.550 & 0.101 & 1.056 & 1.048 & 0.550 & 0.263 & 0.110 & $3.65 \mathrm{E}-07$ \\
\hline 0.550 & 0.109 & 1.101 & 1.073 & 0.550 & 0.263 & 0.110 & 8.05E-07 \\
\hline 0.550 & 0.114 & 1.151 & 1.117 & 0.550 & 0.263 & 0.110 & 8.76E-07 \\
\hline 0.550 & 0.114 & 1.151 & 1.114 & 0.550 & 0.263 & 0.110 & $9.73 \mathrm{E}-07$ \\
\hline 0.550 & 0.128 & 1.205 & 1.188 & 0.550 & 0.263 & 0.110 & 2.19E-06 \\
\hline 0.550 & 0.136 & 1.264 & 1.210 & 0.550 & 0.263 & 0.110 & $3.24 \mathrm{E}-06$ \\
\hline 0.550 & 0.149 & 1.330 & 1.286 & 0.550 & 0.263 & 0.110 & 4.07E-06 \\
\hline 0.550 & 0.100 & 1.484 & 1.420 & 0.550 & 0.263 & 0.110 & $1.44 \mathrm{E}-07$ \\
\hline 0.550 & 0.109 & 1.679 & 1.505 & 0.550 & 0.263 & 0.110 & 3.76E-07 \\
\hline
\end{tabular}




\begin{tabular}{|c|c|c|c|c|c|c|c|}
\hline 0.550 & 0.116 & 1.679 & 1.586 & 0.550 & 0.263 & 0.110 & 8.77E-07 \\
\hline 0.550 & 0.130 & 1.796 & 1.737 & 0.550 & 0.263 & 0.110 & $1.15 \mathrm{E}-06$ \\
\hline 0.550 & 0.143 & 2.090 & 1.886 & 0.550 & 0.263 & 0.110 & $1.11 \mathrm{E}-05$ \\
\hline 0.550 & 0.156 & 2.276 & 2.023 & 0.550 & 0.263 & 0.110 & $3.11 \mathrm{E}-05$ \\
\hline 0.550 & 0.091 & 2.276 & 2.174 & 0.550 & 0.263 & 0.110 & $1.89 \mathrm{E}-07$ \\
\hline 0.550 & 0.108 & 2.498 & 2.390 & 0.550 & 0.263 & 0.110 & $5.38 \mathrm{E}-06$ \\
\hline 0.550 & 0.127 & 3.103 & 2.644 & 0.550 & 0.263 & 0.110 & 4.26E-05 \\
\hline 0.550 & 0.143 & 3.531 & 2.683 & 0.550 & 0.263 & 0.110 & $1.90 \mathrm{E}-04$ \\
\hline
\end{tabular}

Table 7. Cubipod 1L small-scale tests by Smolka et al. (2009).

\section{References}

Besley, P., 1999. Overtopping of sea-walls-design and assessment manual. R \& D Technical Report 178, Environment Agency, Bristol, UK.

Bruce, T., Van der Meer, J.W., Franco, L., Pearson, J.M., 2006. A comparison of overtopping performance of different rubble mound breakwater armour. Proceedings $30^{\text {th }}$ International Conference on Coastal Engineering. World Scientific, Vol. 5, pp. 4567-4579.

Bruce, T., Van der Meer, J.W., Franco, L., Pearson, J.M., 2009. Overtopping performance of different armour units for rubble mound breakwaters. Coastal Engineering 56 (2), 166-179.

Coeveld, E.M., Van Gent, M.R.A., Pozueta, B., 2005. Neural Network, Manual NN_OVERTOPPING 2.0, CLASH: Workpackage 8, http://nn-overtopping.deltares.nl/ (Accessed: July, 2013).

Crest Level Assessment of coastal Structures by full scale monitoring, neural network prediction and Hazard analysis on permissible wave overtopping, http://www.clash.ugent.be/ (Accessed: July, 2013). 
EurOtop, 2007. Wave Overtopping of Sea Defences and Related Structures: Assessment Manual (EurOtop Manual). Pullen, T., Allsop, N.W.H., Bruce, T., Kortenhaus, A., Schüttrumpf, H., Van der Meer, J.W. Environment Agency, UK/ENW Expertise Netwerk Waterkeren, NL/KFKI Kuratorium für Forschung im Küsteningenieurwesen, Germany, http:// www.overtopping-manual.com (Accessed: July, 2013).

Hebsgaard, M., Sloth, P., Juul, J., 1998. Wave overtopping of rubble mound breakwaters. Proceedings $26^{\text {th }}$ International Conference on Coastal Engineering. ASCE, Vol. 3, pp. 2235-2248.

Kortenhaus, A., Vloebergh, H., Weymeis, M., De Rouck, J., Gallach-Sánchez, D., Troch, P., 2014. Improved understanding of stability and overtopping performance of single layer Haro blocks on rubble mound breakwaters. Proceedings 5th International Conference on the Application of Physical Modelling to Port and Coastal Protection, Vol. 1, pp. 279-288.

Lykke-Andersen, T., Burchart, H. F., 2004. Report on additional tests, part A: Effect of obliqueness, short-crested waves and directional spreading. CLASH WP3 report, Aalborg University, Denmark.

Medina, J.R., Molines, J., Gómez-Martín, M.E., 2014. Influence of Armour Porosity on the Hydraulic Stability of Cube Armour Layers. Ocean Engineering 88, 289-297.

Owen, M.W., 1980. Design of seawalls allowing for wave overtopping. HR Wallingford, Report EX 924.

Pearson, J., Bruce, T., Franco, L., Van der Meer, J., Falzacappa, M., Molino, R., 2004. Report on additional tests, part B: Standard tests for roughness factors, CLASH WP4 report, University of Edinburgh, UK. 
Pedersen, J., 1996. Wave forces and overtopping on crown walls of rubble mound breakwaters. Series paper 12, Hydraulic and Coastal Engineering Laboratory, Department of Civil Engineering, Aalborg University, Denmark.

Smolka, E., Zarranz, G., Medina, J.R., 2009. Estudio Experimental del Rebase de un Dique en Talud de Cubípodos. Libro de las X Jornadas Españolas de Costas y Puertos, Universidad de Cantabria-Adif Congresos, pp. 803-809 (in Spanish).

Stewart, T.P., Newberry, S.D., Simm, J.D., Latham, J.P., 2002. The hydraulic performance of tightly packed rock armour layers. Proceedings $28^{\text {th }}$ International Conference on Coastal Engineering. World Scientific, Vol. 2, pp. 1449-1471.

TAW, 1974. Wave run-up and overtopping. Technical Advisory Committee on Water Defences in The Netherlands. Government Publishing Office, The Hague, The Netherlands.

Van der Meer, J.W., Janssen, J.P.F.M., 1994. Wave Run-Up and Wave Overtopping at Dikes, Delft Hydraulics No. 485.

Van der Meer, J.W., Verhaeghe, H., Steendam, G.J., 2009. The new wave overtopping database for coastal structures. Coastal Engineering 56 (2), 108-120.

Van der Meer, J.W., Bruce, T., 2014. New Physical Insights and Design Formulas on Wave Overtopping at Sloping and Vertical Structures. Journal of Waterway, Port, Coastal and Ocean Engineering 140 (6), 04014025.

Van Gent, M.R.A., Van den Boogaard, H.F.P., Pozueta, B., Medina, J.R., 2007. Neural network modelling of wave overtopping at coastal structures. Coastal Engineering $54(8), 586-593$. 
Verhaeghe, H., Van der Meer, J.W., Steendam, G.J., Besley, P., Franco, L., Van Gent, M.R.A., 2003. Wave overtopping database as the starting point for a neural network prediction method. Proceedings Coastal Structures 2003. ASCE, pp. 418-430. 